\title{
Prediction of electrolyte refresh time for Mg-Air battery
}

\author{
Jongwoo Park ${ }^{1,2}$, Kwangyeop Jang ${ }^{4}$, Sangwon Seo ${ }^{1,2}$, Jaehyo Park ${ }^{1,2}$, Wansung Kwon ${ }^{1,2}$, and Dongjin Kim ${ }^{1,2,3 *}$ \\ ${ }^{1}$ SUNKWANG L.T.I. INC., Central Research Institute of Technology, Seoul, Republic of Korea \\ ${ }^{2}$ SUNKWANG L.T.I. INC., Institute of Field Research Center, Seoul, Republic of Korea \\ ${ }^{3}$ SUNKWANG L.T.I. INC., Head-Quarter, Seoul, Republic of Korea \\ ${ }^{4}$ Korea Conformity Laboratories, Parts and Materials Headquarters, Seoul, Republic of Korea
}

\begin{abstract}
In order to understand when to replace the electrolyte of the Mg-Air battery, the effect of the surface area of Metal anode according to the consumption. For each capacity of the Mg-Air battery pack on the electrolyte concentration was calculated, the timing of electrolyte replacement was predicted.
\end{abstract}

\section{Introduction}

Recently, the need for high-capacity batteries has emerged due to the rapid growth of the Smart E-mobility market. Therefore, lithium ion battery with the highest energy density are used to for most E-mobility. However, currently used lithium-ion batteries are approaching technological limits, and development of batteries having higher energy density is required.

For this reason, research on Metal-Air Batteries having a higher density than lithium-ion batteries has been actively conducted in recent years. Among them, Mg-Air batteries using $\mathrm{Mg}$ metal as fuel are evaluated as economical and eco-friendly metal fuel cells because of high energy density and abundant storage of $\mathrm{Mg}$ and $\mathrm{NaCl}$ electrolyte.[1,2]

Mg-air battery is a chemical battery that discharges electromotive force to the outside by oxidation of Metal anode, and reduction of air cathode. It has a very high utility value as a commercial power source in terms of stability and economy. When it is used as an emergency or auxiliary power source for E-mobility, its value is expected to increase further in terms of lifespan and maintenance.

Therefore, research results on the factors affecting the output of Mg-Air batteries have been reported for commercialization. Among several factors that affect the output of Mg-Air battery, the concentration of $\mathrm{NaCl}$ electrolyte is actually a very important factor.[3,4]

In order to apply the Mg-Air battery to E-mobility, it is very important to maintain the output to meet the torque of the electronic motor. Therefore, The Mg-Air batteries electrolyte should be replaced to maintain the Mg-Air batteries output at an appropriated level.

Therefore, in this paper, the effect of the change in the active reaction area according to the surface change according to the use of the $\mathrm{Mg}$ anode on the $\mathrm{NaCl}$ electrolyte concentration was calculated, Predict the replacement timing according to the capacity of the $\mathrm{Mg}$ Air battery

\section{Electrolyte refresh of $\mathrm{Mg}$-Air battery}

\subsection{Structure and output of Mg-Air battery}

Figure 1 is a Unit Cell of the Mg-Air battery Used in this study. This battery is a chemical battery that generates electromotive force through the oxidation of the $\mathrm{Mg}$ anode and reduction of Air cathode.

In the Standard state, the complete reaction equation combining the oxidation of $\mathrm{Mg}$ anode and reduction of Air cathode is shown in equation (1)

$$
2 \mathrm{Mg}+\mathrm{O} 2+2 \mathrm{H} 2 \mathrm{O} \rightarrow 2 \mathrm{Mg}(\mathrm{OH}) 2
$$
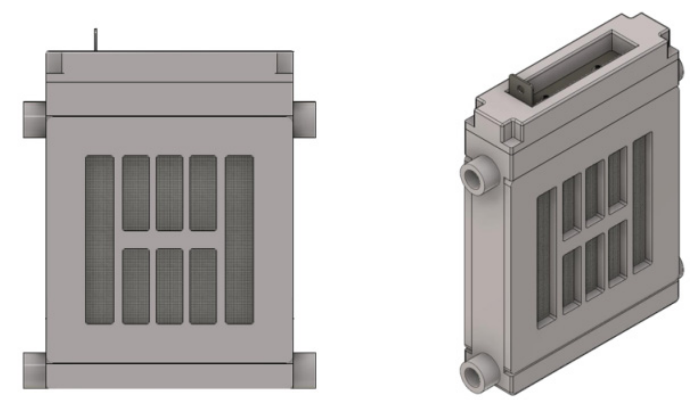

Figure 1. Configuration of the Mg-Air battery unit cell

As can be seen from the complete reaction equation in equation (1), $\mathrm{H}_{2} \mathrm{O}$ inside the electrolyte is used in the power generation process, so the concentration of the electrolyte increases as power generation proceeds.

In order to check the output of Mg-Air batteries according to the concentration of $\mathrm{NaCl}$ electrolyte, 25 $\mathrm{Mg}$-Air batteries were connected in series to form a battery pack, and the output voltage was checked by changing the concentration. Figure 2 Shows the output voltage of $\mathrm{Mg}$-Air battery pack according to the concentration of the electrolyte.

\footnotetext{
$\overline{{ }^{a} \text { Corresponding author: djkim@i-sk.com }}$
} 


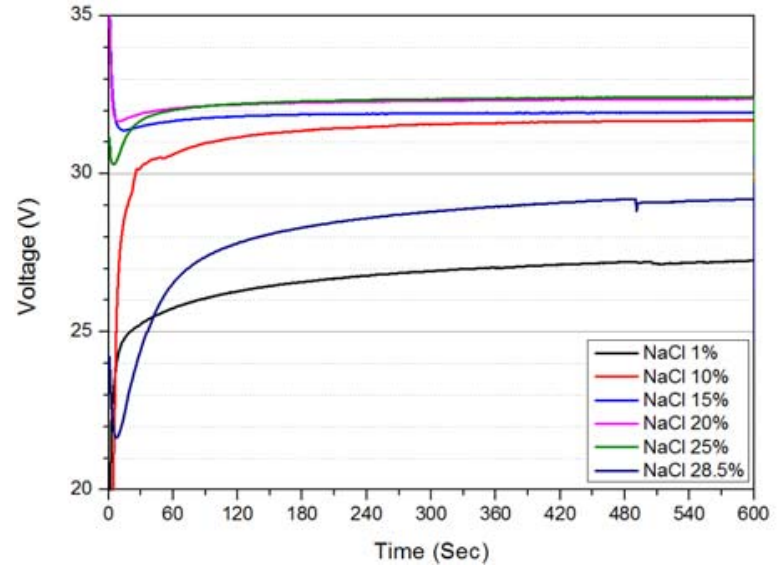

Figure 2. Output voltage of Mg-Air battery pack according to $\mathrm{NaCl}$ electrolyte concentration.

At a concentration between $20 \mathrm{Wt} \%$ and $25 \mathrm{Wt} \%$, the output was about $1.28 \mathrm{~V} / \mathrm{Cell}$ and when the concentration decreased or increased, the output voltage tended to decrease. Accordingly, the optimal operating electrolyte concentration of the Mg-air battery pack for E-mobility application was selected from $20 \mathrm{Wt} \%$ to $25 \mathrm{Wt} \%$, the effect of the change in the surface area of the $\mathrm{Mg}$ anode according to power generation on the concentration of electrolyte was calculated through numerical analysis.

\subsection{Electrolyte-Surface Curve fitting}

In order to calculate the surface area of $\mathrm{Mg}$ anode according to the consumption, the following two premises are required.

The first premise is 'The roughness of the Mg-anode is always constant during the power generation process.'

The second premise is 'Each side of the $\mathrm{Mg}$ anode is consumed at the same rate.'

Based on this premise, the volume of the Mg-anode was calculated by dividing the weight and density as shown in equation (2)

$$
\begin{aligned}
& =\frac{850 \mathrm{~g}}{1 E A}(\text { weight of } \mathrm{Mg}) \div \frac{1.738 \mathrm{~g}}{\mathrm{~cm}^{3}}(\text { Density of } \mathrm{Mg}) \\
& \cong 490 \mathrm{~cm}^{3} / E A(\text { Volume of } \mathrm{Mg} \text { anode })
\end{aligned}
$$

And then, the dimensions of the initial Mg anode were calculated based on the drawing data, and the length of each side of the cathode was calculated according to the consumption amount of the $\mathrm{Mg}$ anode. Table 1 shows the surface area of a unit Mg-Air battery according to the amount of $\mathrm{Mg}$ anode consumption.

Table 1. Surface area calculation for $\mathrm{Mg}$ anode consumption in unit Mg-Air Battery

\begin{tabular}{|c|c|c|c|c|c|}
\hline $\begin{array}{c}\text { Usage } \\
{[\%]}\end{array}$ & $\begin{array}{c}\text { Weight } \\
{[\mathbf{g}]}\end{array}$ & $\begin{array}{c}\text { Volume } \\
{\left[\mathbf{c m}^{\mathbf{3}}\right]}\end{array}$ & $\begin{array}{c}\text { Width } \\
{[\mathbf{c m}]}\end{array}$ & $\begin{array}{c}\text { Depth } \\
{[\mathbf{c m}]}\end{array}$ & $\begin{array}{c}\text { Height } \\
{[\mathbf{c m}]}\end{array}$ \\
\hline 0 & 850 & 490 & 12.20 & 2.00 & 20.04 \\
\hline 10 & 765 & 440 & 11.78 & 1.93 & 19.35 \\
\hline 20 & 680 & 391 & 11.33 & 1.86 & 18.61 \\
\hline 30 & 595 & 342 & 10.83 & 1.77 & 17.78 \\
\hline 40 & 510 & 293 & 10.30 & 1.69 & 16.92 \\
\hline 50 & 425 & 244 & 9.68 & 1.59 & 15.90 \\
\hline 60 & 340 & 195 & 8.98 & 1.47 & 14.76 \\
\hline
\end{tabular}

\begin{tabular}{|c|c|c|c|c|c|}
\hline 70 & 255 & 146 & 8.17 & 1.34 & 13.43 \\
\hline 80 & 170 & 97 & 7.14 & 1.17 & 11.72 \\
\hline 90 & 85 & 48 & 5.66 & 0.93 & 9.30 \\
\hline 99.99 & 0.0004 & 0.0002 & 0.09 & 0.01 & 0.16 \\
\hline
\end{tabular}

Using the length of the $\mathrm{Mg}$ anode side, calculate the surface area according to the $\mathrm{Mg}$ anode consumption and it was extended to a battery pack in which $25 \mathrm{Mg}$-Air battery connected in series, and data was converted using the $\ln$ function.

Table 2. Calculation of surface area for consumption of $\mathrm{Mg}$ anode in $25 \mathrm{~S}$ battery pack

\begin{tabular}{|c|c|c|c|c|c|}
\hline $\begin{array}{c}\text { Usage } \\
{[\%]}\end{array}$ & $\begin{array}{c}\text { Front } \\
\text { and } \\
\text { Rear } \\
{\left[\mathbf{c m}^{2}\right]}\end{array}$ & $\begin{array}{c}\text { Right } \\
\text { and } \\
\text { Left } \\
{\left[\mathbf{c m}^{2}\right]}\end{array}$ & $\begin{array}{c}\text { Bottom } \\
{\left[\mathbf{c m}^{2}\right]}\end{array}$ & $\begin{array}{c}\text { Sum of } \\
\text { Surface } \\
{\left[\mathbf{c m}^{2}\right]}\end{array}$ & $\mathbf{1 / n S}$ \\
\hline 0 & 244.5 & 40.1 & 24.4 & 14383.4 & 0.1041 \\
\hline 10 & 227.9 & 37.4 & 22.8 & 13833.6 & 0.1048 \\
\hline 20 & 210.8 & 34.6 & 21.0 & 12793.5 & 0.1058 \\
\hline 30 & 192.5 & 31.6 & 19.2 & 11685.1 & 0.1068 \\
\hline 40 & 174.2 & 28.6 & 17.4 & 10575.3 & 0.1079 \\
\hline 50 & 153.9 & 25.2 & 15.4 & 9341.78 & 0.1093 \\
\hline 60 & 132.6 & 21.7 & 13.2 & 8046.28 & 0.1112 \\
\hline 70 & 109.7 & 18.0 & 10.9 & 6660.24 & 0.1136 \\
\hline 80 & 83.6 & 13.7 & 8.4 & 5075.52 & 0.1172 \\
\hline 90 & 54.6 & 8.63 & 5.3 & 3195 & 0.1239 \\
\hline 99.99 & 0.01 & 0.002 & 0.00 & 0.03 & 1.0209 \\
\hline
\end{tabular}

Table 2 shows the surface area for the Mg-Air anode consumption of the Mg-Air battery pack composed of the $25 \mathrm{~S}$ structure.

The concentration of the electrolyte in the battery due to the power generation was calculated through the total volume of the $\mathrm{Mg}$-air battery pack, the amount of $\mathrm{H}_{2} \mathrm{O}$ in the electrolyte compared to the amount of Mg-anode consumption was calculated by complete reaction from equation (1). Based on the above data, an electrolyte limit concentration curve for surface area of the $\mathrm{Mg}$ anode of battery pack by capacity was fitted. (E-S limit curve)

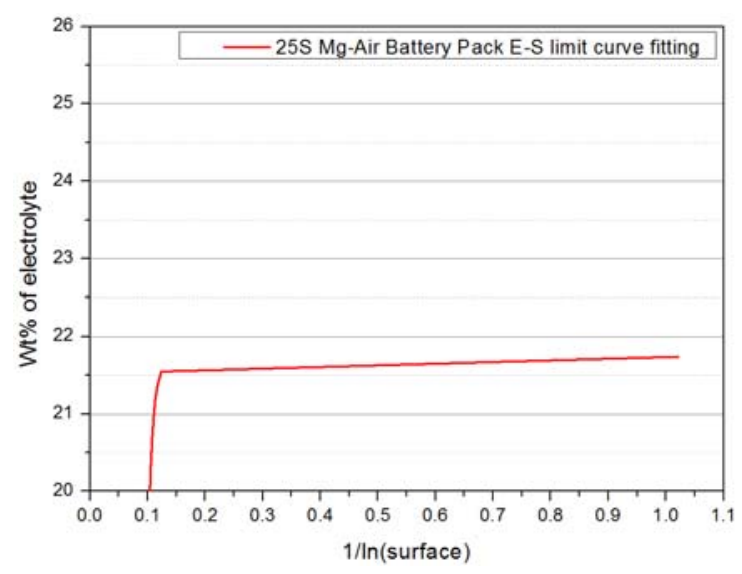

Figure 3. E-S limit curve of $25 \mathrm{~S}$ Mg-Air battery pack 
Figure 3 shows the Electrolyte-Surface limit curve of 25S Mg-Air battery pack. When the initial electrolyte concentration of the $25 \mathrm{~S} \mathrm{Mg}$-Air battery pack is calculated as $20 \mathrm{Wt} \%$, the concentration of the electrolyte is $21.74 \mathrm{Wt} \%$ when all the $\mathrm{Mg}$ anodes of the battery pack are exhausted.

Through this, it can be confirmed that it is within the range of electrolyte concentration that can produce the optimal output. The E-S limit curve of $25 \mathrm{~S} \mathrm{Mg-Air} \mathrm{battery}$ pack is fitted as equation (3)

Electrolyte Wt\% $=-\mathrm{k} \times e^{\frac{1 / \ln (\text { surface of Mg anode })}{0.00814}}+\alpha$

$\mathrm{k}=-6.12 \times 10^{5}, \alpha=21.72271$

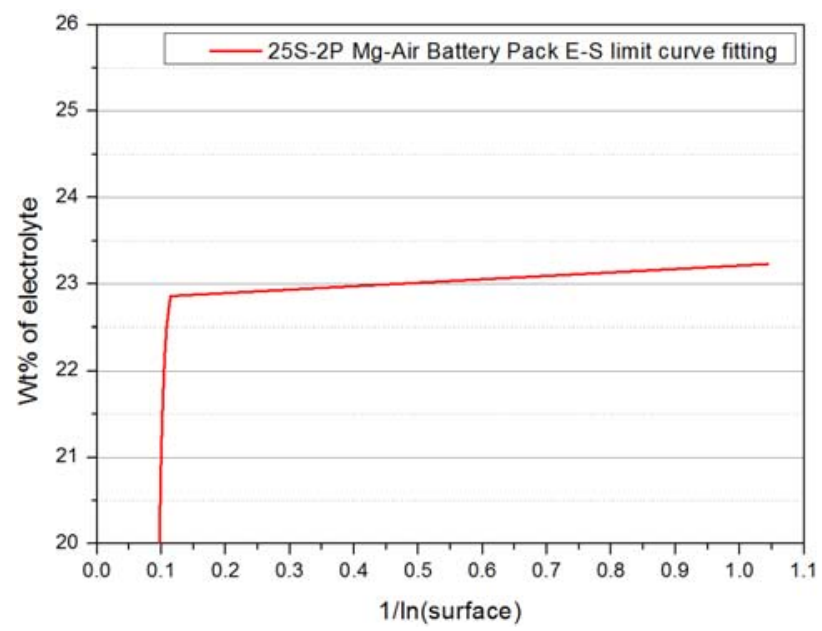

Figure 4. E-S limit curve of 25S-2P Mg-Air battery pack

Figure 4 shows the Electrolyte-Surface limit curve of 25S-2P Mg-Air battery pack (Unit Mg-Air battery 50EA). When the initial electrolyte concentration of the 25S-2P Mg-Air battery pack is calculated as $20 \mathrm{Wt} \%$, the concentration of the electrolyte is $23.23 \mathrm{Wt} \%$ when all the $\mathrm{Mg}$ anodes of the battery pack are exhausted.

Through this, it can be confirmed that it is within the range of electrolyte concentration that can produce the optimal output. The E-S limit curve of 25S-2P Mg-Air battery pack is fitted as equation (4)

Electrolyte $\mathrm{Wt} \%=-\mathrm{k} \times e^{\frac{1 / \ln (\text { surface of } \mathrm{Mg} \text { anode })}{0.00739}}+\alpha$

$\mathrm{k}=-1.62 \times 10^{6}, \alpha=23.20917$

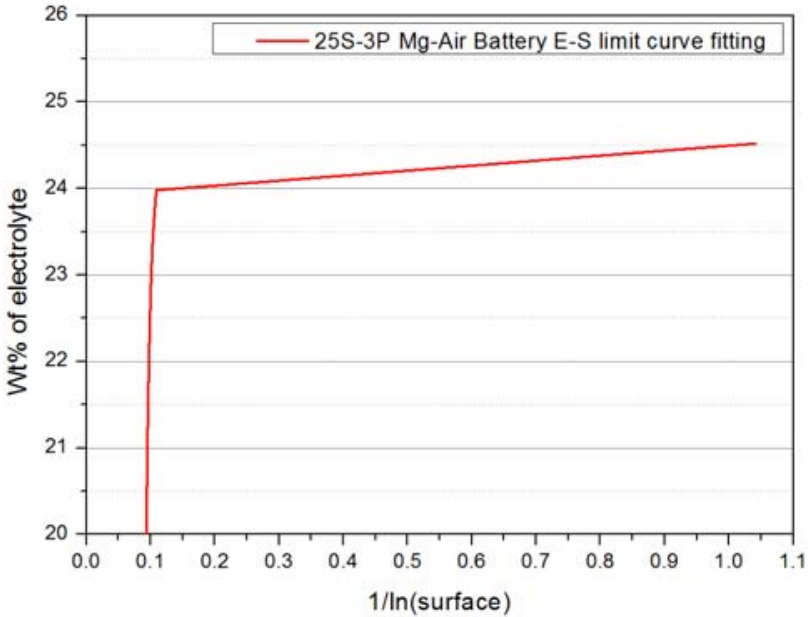

Figure 5. E-S limit curve of 25S-3P Mg-Air battery pack

Figure 5 shows the Electrolyte-Surface limit curve of 25S-3P Mg-Air battery pack (Unit Mg-Air battery 75EA). When the initial electrolyte concentration of the 25S-3P $\mathrm{Mg}$-Air battery pack is calculated as $20 \mathrm{Wt} \%$, the concentration of the electrolyte is $24.52 \mathrm{Wt} \%$ when all the $\mathrm{Mg}$ anodes of the battery pack are exhausted.

Through this, it can be confirmed that it is within the range of electrolyte concentration that can produce the optimal output. The E-S limit curve of 25S-3P Mg-Air battery pack is fitted as equation (5)

Electrolyte Wt\% $=-\mathrm{k} \times e^{\frac{1 / \ln (\text { surface of } M g \text { anode })}{0.00709}}+\alpha$

$\mathrm{k}=-2.36 \times 10^{6}, \alpha=24.50338$

Figure 6 shows the Electrolyte-Surface limit curve of 25S-4P Mg-Air battery pack (Unit Mg-Air battery 100EA). When the initial electrolyte concentration of the 25S-4P Mg-Air battery pack is calculated as $20 \mathrm{Wt} \%$, when $90 \%$ of the $\mathrm{Mg}$ anode consumed, the concentration of the electrolyte is $24.95 \mathrm{Wt} \%$. When all of $\mathrm{Mg}$ anode were exhausted, the concentration of electrolyte is $25.65 \mathrm{Wt} \%$

Through this, it can be confirmed that the electrolyte concentration was out of the way for the optimal output. The E-S limit curve of 25S-3P Mg-Air battery pack is fitted as equation (6)

Electrolyte Wt\% $=-\mathrm{k} \times e^{\frac{1 / \ln (\text { surface of } M g \text { anode })}{0.00691}}+\alpha$

$\mathrm{k}=2.97 \times 10^{6}, \alpha=25.63905$ 


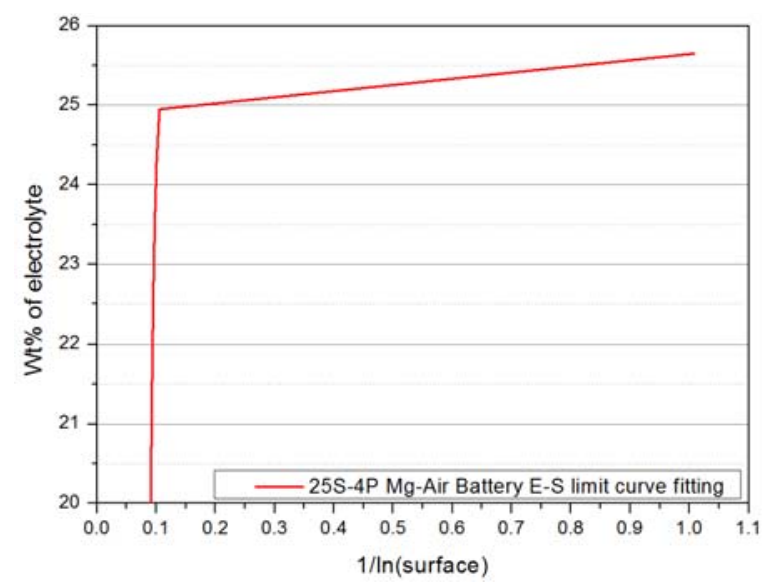

Figure 6. E-S limit curve of 25S-4P Mg-Air battery pack

From the results, when the capacity of the Mg-air battery pack is above a certain level, it is out of the optimum operating electrolyte concentration range before the $\mathrm{Mg}$ anode is exhausted. It can be seen that the timing of electrolyte replacement is necessary.

\section{Conclusion}

In order to apply the Mg-Air battery to Smart E-mobility, it is necessary to calculate the electrolyte replacement according to the electrolyte concentration.

By calculating the effect of the Mg anode surface area on the electrolyte concentration according to the consumption amount of the $\mathrm{Mg}$ anode for each $\mathrm{Mg}$-air battery pack capacity, the timing of electrolyte replacement was predicted when the Mg-Air battery was actually applied to E-mobility.

If the capacity of the Mg-Air battery pack exceeds a certain level, it is out of the optimum operating electrolyte range before the $\mathrm{Mg}$ anode is exhausted, it was necessary to identify and replace the electrolyte for the capacity.

\section{Acknowledgments}

This research was supported by the Technology Innovation Program (20001088, Development of environment friendly personal emobility products and experiential sharing platform service design based on tourismlesport) funded By the Ministry of Trade, industry \& Energy (MI, Korea)

\section{References}

1. Z. H-Y, B. Pei and J.U dongwing, J. Environmental sciences supplement, s88-s91 (2009)

2. Ding. W. J. Science press (2007)

3. A. Kaisheva, protable and emergency energy sourcefrom materials to systems, 16-22 (2005)

4. L. Chen, et al, Chin. Sci. Bull, 1936-1941 (2014)

5. S. Sathyanarayna and B.V.Ratnakumar, J. Power Sources, 10, 243-261 (1983)
6. B.V. Ratnakumar and S.Sathyanarayana, J. Power sources, 12, 39-51 (1984)

7. R. Roffia, V.conicalini, and C. Pardisi, J. Chem. Educ. 65, 3(1988)

8. J.H Kim, S.U, Uum, S. E. Moon, M.S Youn, J.Y. Kim, J.S. Park, and J.H. Park, J.KIEE. 17, 4 (2004)

9. D.A.J. Rand, R. Woods, and R.M. Dell, Batteries for Electric Vechicles (John Wiley \& Sons Inc, 1998)

10. K. F. Blurton, and A. F. Sammells, J. Power source, 4 (1979)

11. A. Perujo, and K. Douglas, Storage technology report WPST 9 (2002)

12. Y.H. Kim J. KIEEME, 23, 1002-1006 (2010)

13. Y.H. Kim, Trans KIEE 59, 9(2010) 